\title{
Aplikasi Pendaftaran Rawa BaTIK (Ruang Aktivitas Warga Belajar Aplikasi dan TIK) Berbasis Web
}

\author{
Much Rifani ${ }^{1)}$, Jaka Permadi ${ }^{2}$ \\ Jurusan Teknik Informatika, Politeknik Negeri Tanah Laut \\ ${ }^{1)}$ muchrifani@gmail.com \\ 2)jakapermadi.88@politala.ac.id
}

\begin{abstract}
Abstrak
Dinas Komunikasi dan Informatika (Diskominfo) Kabupaten Tanah Bumbu memiliki program yang sedang digiatkan yaitu Ruang Aktivitas Warga Belajar Aplikasi dan TIK (Rawa BaTIK). Program tersebut bertujuan untuk memberikan kesempatan bagi pelajar dan masyarakat untuk dapat belajar TIK di pusat study Diskominfo. Permasalahan yang muncul yaitu calon peserta harus mendaftar langsung di kantor Diskominfo, dimana lokasi pendaftaran tersebut cukup jauh dari pusat kota. Berdasarkan permasalahan tersebut dibangunlah aplikasi pendaftaran Rawa BaTIK berbasis web. Pembangunan aplikasi dimulai dari tahap perumusan masalah, pengumpulan data dan pengembangan sistem. Permasalahan yang muncul adalah bagaimana membangun aplikasi Rawa BaTIK berbasis web. Pengumpulan data dilakukan menggunakan metode wawancara dengan Sekretaris Diskominfo Tanah Bumbu terkait kebutuhan dari aplikasi yang dibangun. Pengembangan sistem yang dilakukan menggunakan model waterfall, dimana perancangannya menggunakan ERD, DFD dan flowchart, dan bahasa pemrograman yang digunakan adalah HTML, PHP dan JavaScript. Aplikasi tersebut sudah diuji menggunakan metode Black Box Testing dengan hasil pengujian menunjukkan bahwa semua fungsionalitas dari aplikasi pendaftaran Rawa BaTIK berjalan seluruhnya.
\end{abstract}

Kata kunci : aplikasi pendaftaran, pengujian Black Box, waterfall

\section{Abstract}

The Communication and Information Department (Diskominfo) of Tanah Bumbu Regency has a program that is being intensified, namely the Citizen Activities Room for Applications and ICT Learning (Rawa BaTIK). The program aims to provide opportunities for students and communities to be able to learn ICT in Diskominfo study center. The problem is the prospective participants should register directly at the Diskominfo office, where the registration location is quite far from city center. Based on these problems a web-based application of Rawa BaTIK registration is built. The application development was started from formulation of the problems phase, data collecting phase and then system development phase. The problem was how to build the web-based application of Rawa BaTIK. The collecting data phase then was performed by interview method with Diskominfo's secretary of Tanah Bumbu about requirements of the application. The system development was performed by waterfall model, where the design used ERD, DFD and flowchart, and the programming languages are HTML, PHP and JavaScript. The application is tested using Black Box Testing method with the test results show that all the functionallity of Rawa BaTIK registration application works entirely.

Keywords : registration application, Black Box testing, waterfall

\section{PENDAHULUAN}

Dinas Komunikasi dan Informatika (Diskominfo) Kabupaten Tanah Bumbu, Kalimantan Selatan dalam Rencana Strategis 2016-2020 memiliki program dan kegiatan pembangunan di bidang Komunikasi dan Informatika berdasarkan kondisi dan potensi daerah di Kabupaten Tanah Bumbu. Salah satu program yang sedang digiatkan adalah Ruang Aktivitas Warga Belajar Aplikasi dan TIK (Rawa BaTIK). Program tersebut bertujuan untuk memberikan kesempatan bagi pelajar dan masyarakat untuk dapat belajar TIK di dalam pusat study Diskominfo.

Calon peserta Rawa BaTIK diharuskan mendaftar terlebih dahulu di Kantor Diskominfo Kabupaten Tanah Bumbu. Kantor Diskominfo sendiri lokasinya cukup jauh dari pusat Kabupaten Tanah Bumbu, sehingga pendaftaran kepesertaan yang dilakukan cukup memberatkan calon peserta didik. Proses pendaftaran pun masih dilakukan dengan melakukan pengisian berkas, dimana menimbulkan permasalahan ketika dilakukan pencarian terhadap berkas pendaftaran.

Permasalahan tersebut di atas dapat diselesaikan dengan membangun sebuah aplikasi pendaftaran berbasis web. Menurut Solihin (2015) pada penelitiannya yang berjudul "Perancangan Perangkat 
Lunak Sistem Informasi pada Lembaga Kursus Komputer", suatu aplikasi pendaftaran dapat memecahkan permasalahan menumpuknya berkas pendaftaran pada pendaftaran yang dilakukan secara manual.

Penelitian yang dilakukan oleh Shahfira (2015) yang berjudul "Aplikasi Pendaftaran dan Penjadwalan Pertandingan Olahraga" memecahkan permasalahan dari kesulitan pencarian informasi pada pendataan manual di KONI Kabupaten Asahan Sumatera Utara. Hasil penelitiannya tersebut menyatakan bahwa aplikasi pendataan yang dibangun membantu kinerja KONI Kabupaten Asahan dalam melakukan pencarian informasi secara cepat. Aplikasi tersebut merupakan aplikasi berbasis web menggunakan PHP dan MySQL sebagai databasenya.

Muslihudin dan Larasati (2014) melakukan pembangunan sistem aplikasi penerimaan mahasiswa baru di STMIK Pringsewu karena pada lembaga tersebut belum melayani pendaftaran mahasiswa baru secara online. Permasalahan yang muncul adalah seiring berjalannya waktu jumlah pendaftar semakin banyak dan tidak sedikit yang berasal dari luar kota, sehingga memerlukan pelayanan secara cepat.

Palilingan, Sinsuw dan Najoan (2014) membangun aplikasi untuk registrasi calon siswa baru di SMAN 9 Manado juga karena pendaftaran calon siswa baru belum dilakukan secara online. Kekurangan dari registrasi manual adalah data registrasi akan sulit dikelola dan rentan hilang. Aplikasi yang dibangun tersebut dapat membantu proses registrasi dengan cepat dan mudah dikelola oleh pihak sekolah.

\section{METODE PENELITIAN}

Penelitian yang dilakukan penulis dalam membangun aplikasi pendaftaran Rawa BaTIK berbasis web diawali dengan perumusan masalah, pengumpulan data, dan pengembangan sistem. Kerangka penelitian tersebut ditunjukkan pada gambar berikut.

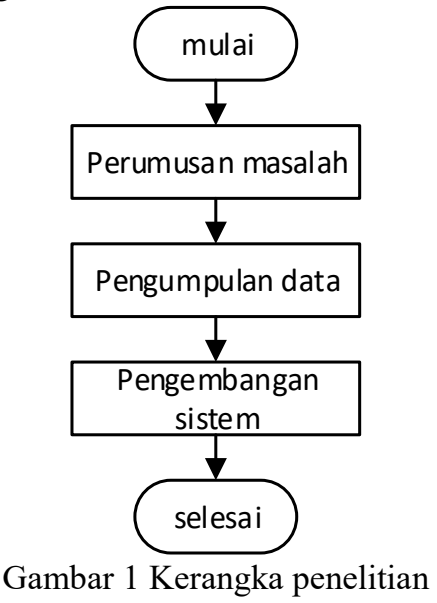

\subsection{Perumusan masalah}

Permasalahan dari penelitian ini adalah bagaimana membangun aplikasi pendaftaran Rawa BaTIK berbasis web yang memiliki fitur sebagai berikut:

1. Peserta dapat mendaftarkan diri melalui aplikasi dan admin mendapatkan informasi pendaftaran dan dapat melakukan pencarian pendaftaran.

2. Peserta yang sudah mendaftar dapat melihat data pengajar, galeri foto kegiatan yang dilakukan dan agenda dari pusat study Rawa BaTIK.

\subsection{Pengumpulan Data}

Metode pengumpulan data yang digunakan adalah wawancara. Penulis melakukan wawancara kepada Bapak Riza Akhyari, S.Kom selaku Sekretaris Diskominfo Kabupaten Tanah Bumbu. Wawancara yang dilakukan terkait kebutuhan dari aplikasi yang dibangun.

\subsection{Pengembangan Sistem}

Pada penelitian terdahulu, Shahfira (2015) dan Suryanto (2016) menggunakan model waterfall 
dalam mengembangkan aplikasi pendaftaran. Model waterfall menyediakan pendekatan dalam pengembangan suatu perangkat lunak dimana setiap tahap/fasenya dilakukan secara berurutan (Sukamto and Shalahuddin 2016). Aplikasi pendaftaran Rawa BaTIK dibangun dengan melalui tahapan analisa kebutuhan sistem, perancangan, pengodean dan pengujian. Model waterfall yang digunakan digambarkan sebagai berikut.

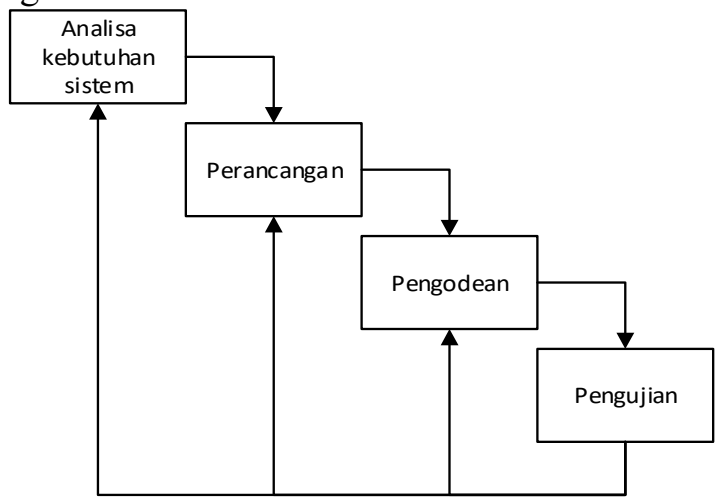

1. Analisa kebutuhan sistem

Gambar 2 Model waterfall

Analisa kebutuhan sistem dilakukan setelah mendapatkan kebutuhan-kebutuhan dari hasil wawancara dengan Sekretaris DISKOMINFO Kabupaten Tanah Bumbu. Kebutuhan-kebutuhan tersebut kemudian dianalisa untuk mendapatkan kebutuhan sistem.

2. Perancangan

Perancangan dilakukan terhadap kebutuhan sistem yang diperoleh dari tahapan sebelumnya. Perancangan dibagi menjadi tiga, yaitu perancangan database, perancangan aliran data, dan perancangan alur sistem. Perancangan database dilakukan dengan menggunakan Entity Relationship Diagram (ERD), perancangan aliran data dilakukan dengan menggunakan Data Flow Diagram (DFD), sementara perancangan alur sistem menggunakan flowchart.

3. Pengodean

Dalam pengodean yang dilakukan, penulis menggunakan bahasa pemrograman HTML, PHP dan JavaScript. Penulis juga menggunakan CSS dan Bootstrap untuk tampilan, dengan text editor yang digunakan adalah Sublime Text 3.

4. Pengujian

Pengujian yang dilakukan adalah pengujian black box, yang menguji aplikasi dari segi spesifikasi fungsional (Sukamto and Shalahuddin 2016). Pengujian dilakukan oleh Sekretaris DISKOMINFO Kabupaten Tanah Bumbu.

\section{HASIL DAN PEMBAHASAN}

\subsection{Gambaran Umum Sistem}

Gambaran umum dari aplikasi pendaftaran Rawa BaTIK ditunjukkan pada gambar berikut. 


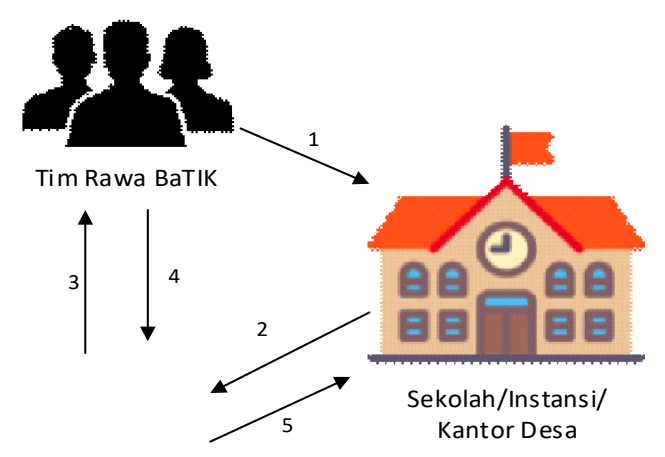

Aplikasi

Pendaftaran

Rawa BaTIK

Gambar 3 Gambaran umum aplikasi pendaftaran Rawa BaTIK

Berikut penjabaran dari gambaran umum aplikasi pendaftaran Rawa BaTIK.

1. Tim Rawa BaTIK melakukan sosialisasi ke sekolah, instansi atau kantor desa untuk memperkenalkan Rawa BaTIK dan juga menunjukkan cara pendaftaran melalui aplikasi pendaftaran Rawa BaTIK.

2. Para peserta yang merupakan pelajar dan masyarakat mendaftarkan kepesertaannya melalui aplikasi pendaftaran Rawa BaTIK.

3. Admin dari Tim Rawa BaTIK mendapatkan informasi mengenai pendaftaran yang dilakukan calon peserta. Di sini admin mengecek kelengkapan berkas pendaftaran dan biodata peserta.

4. Admin memasukkan informasi dan mengelola data pada aplikasi pendaftaran Rawa BaTIK, di antaranya berupa konfirmasi pendaftaran, penginputan mata pelajaran, pengelolaan data pengajar, memasukkan galeri foto kegiatan dan mengelola agenda dari Rawa BaTIK.

5. Peserta yang telah dikonfirmasi dapat melihat agenda, informasi pengajar, galeri foto kegiatan dan mata pelajaran dari Rawa BaTIK. Peserta juga dapat mengelola biodatanya.

\section{$3.2 E R D$}

Ada 11 entitas yang diperlukan untuk pembangunan aplikasi pendaftaran Rawa BaTIK, yaitu akun, pendaftar, peserta, pengajar, kelas, sertifikat, merchandise, galeri_keg, matapelajaran dan agenda. Rancangan ERD dapat dilihat pada gambar berikut.

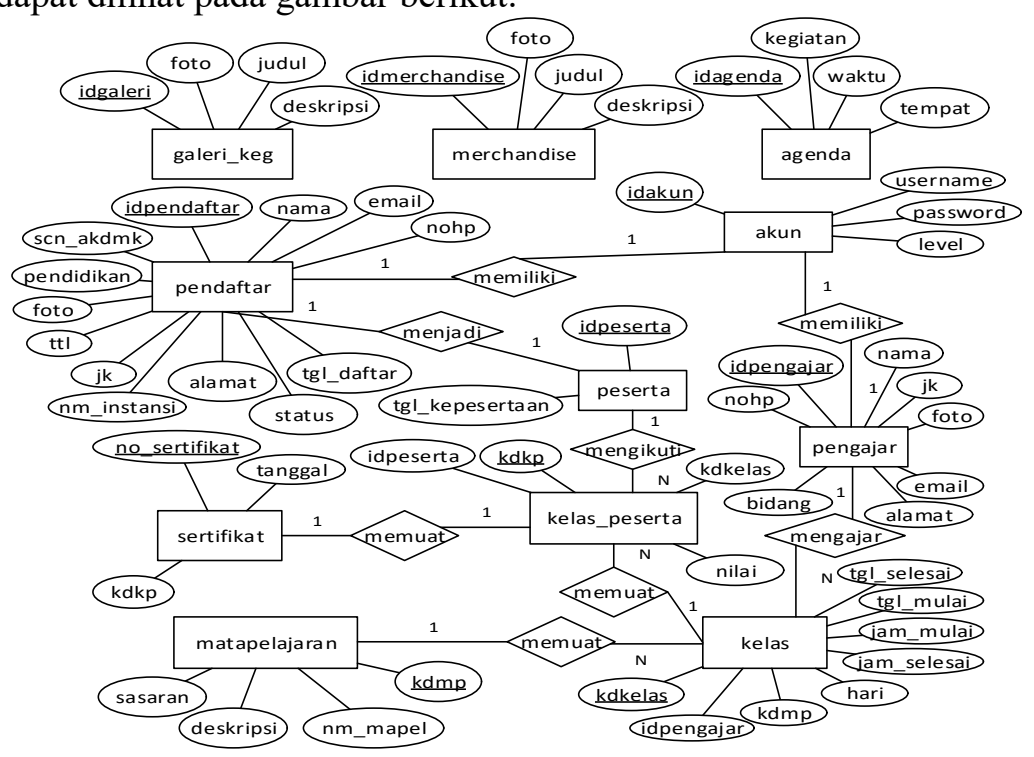

Gambar 4 ERD 


\subsection{DFD}

Pada aplikasi pendaftaran Rawa BaTIK, terdapat 5 level pengguna, yaitu free user, admin, pendaftar, peserta dan pengajar. Free user adalah pengguna yang hanya mendapatkan akses untuk melihat beranda aplikasi, galeri foto kegiatan dan merchandise. Sementara pengguna lainnya harus melakukan Login untuk mendapatkan aksesnya. DFD Level 0 atau Diagram Konteks dari aplikasi pendaftaran Rawa BaTIK dapat dilihat pada gambar berikut.

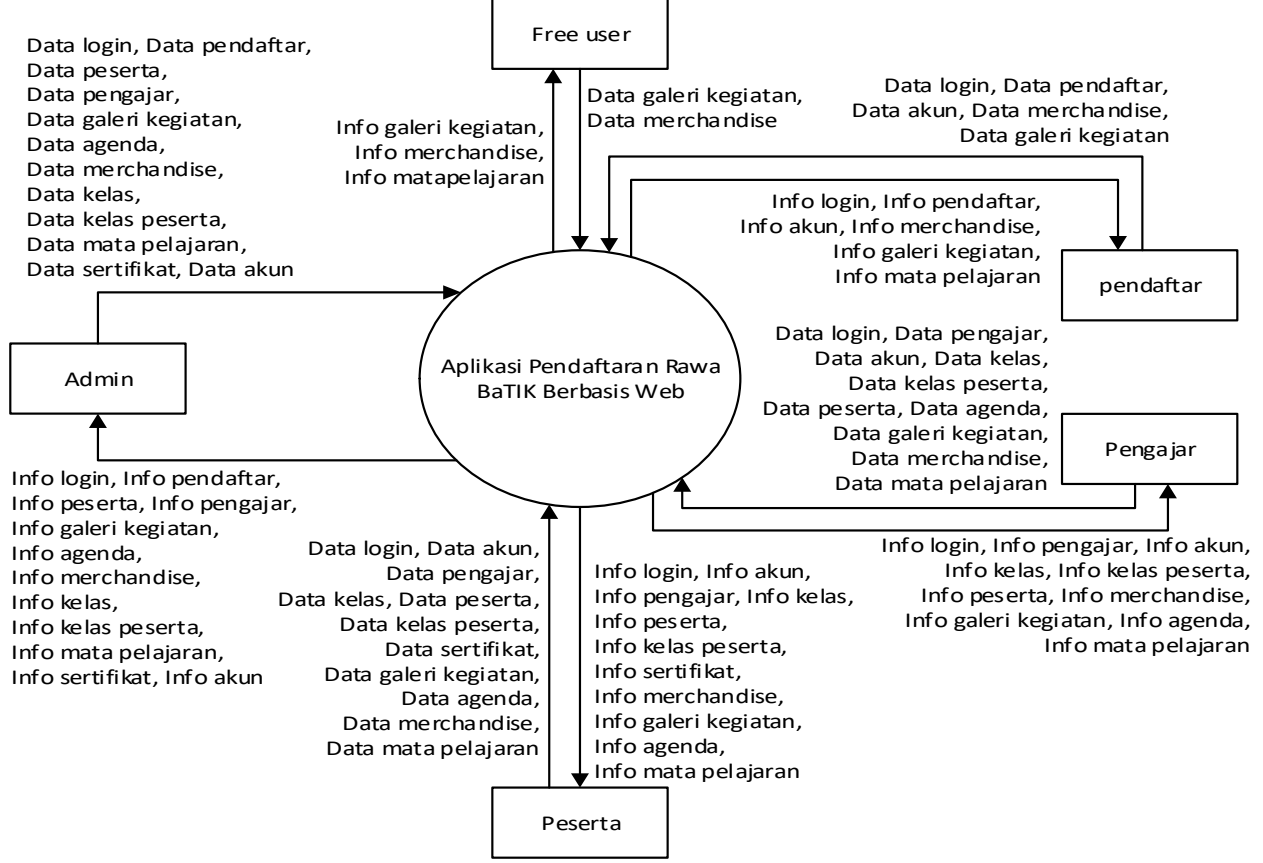

Gambar 5 DFD level 0 (diagram konteks)

\subsection{Flowchart}

\subsubsection{Flowchart beranda free user}

Beranda free user adalah halaman awal dari aplikasi pendaftaran Rawa BaTIK. Pada halaman ini dirancang untuk menampilkan data mata kuliah, data galeri foto kegiatan dan data merchandise. Pada halaman ini juga disediakan menu masuk dan daftar. Flowchart dari halaman beranda free user diperlihatkan pada gambar berikut. 


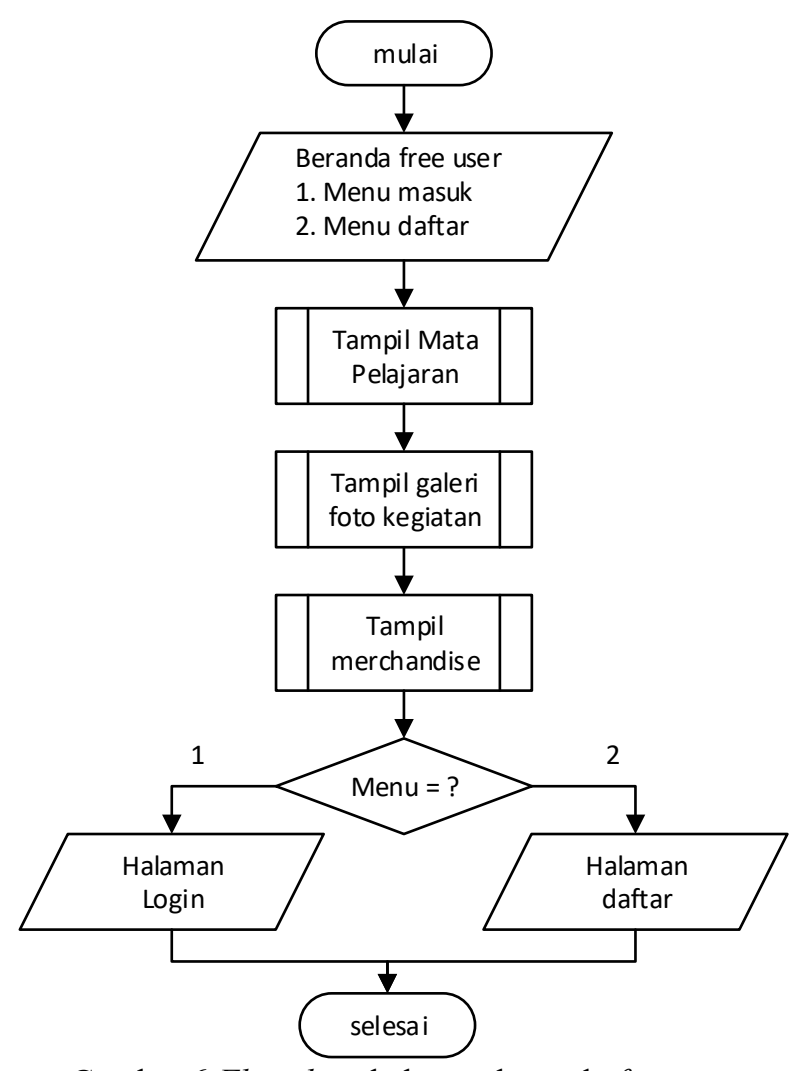

Gambar 6 Flowchart halaman beranda free user

Pada halaman beranda free user, jika menu masuk dipilih, pengguna akan diarahkan ke halaman login. Sementara jika menu daftar dipilih, pengguna akan diarahkan ke halaman daftar.

\subsubsection{Flowchart halaman login}

Halaman login dirancang untuk memiliki beberapa komponen seperti kolom username, kolom password, dan button login. Jika button login maka proses login akan dijalankan. Flowchart dari halaman login ditunjukkan pada gambar berikut.

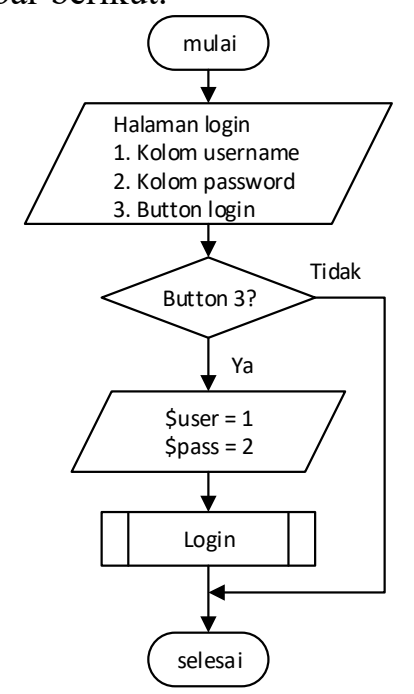

\subsubsection{Flowchart proses login}

Gambar 7 Flowchart halaman login

Ketika username dan password yang dimasukkan merupakan milik admin, maka pengguna akan diarahkan ke halaman admin. Demikian juga untuk pendaftar, peserta dan pengajar, akan diarahkan ke halamannya masing-masing. Pemberian akses ini dirancang pada proses login. Flowchart dari proses 
login ditunjukkan pada gambar berikut.

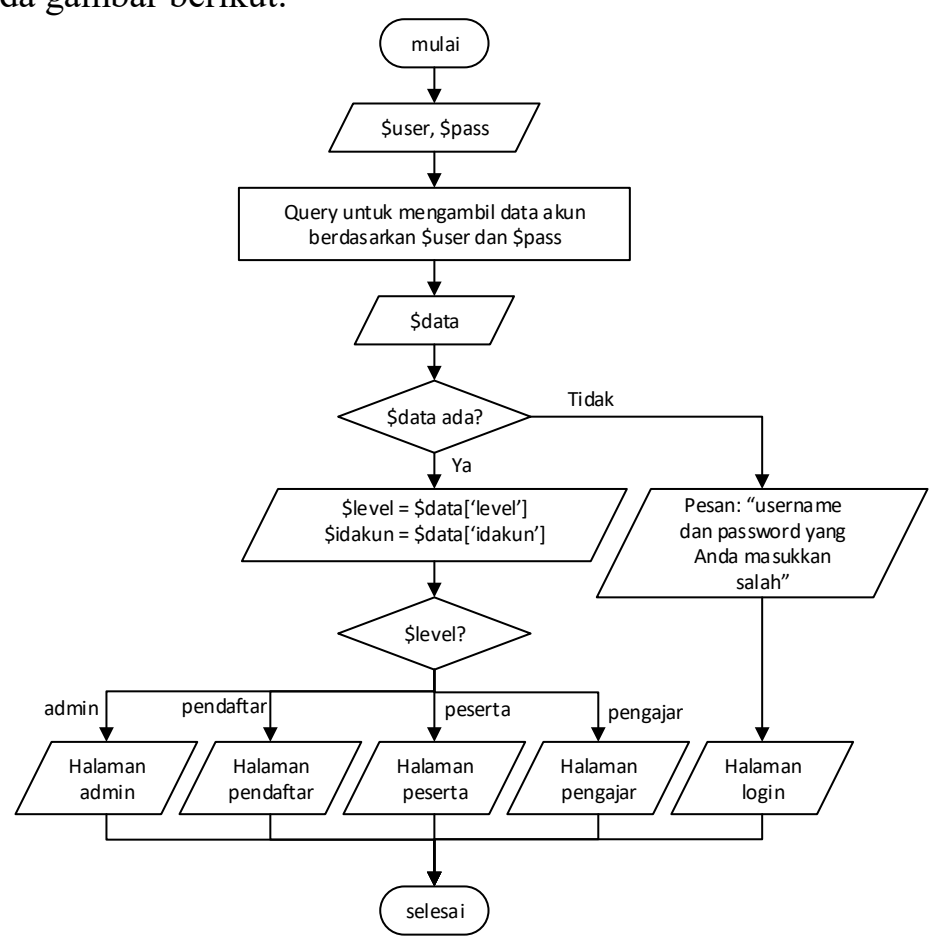

Gambar 8 Flowchart proses login

\subsection{Implementasi}

\subsubsection{Halaman free user}

Setiap pengguna yang membuka aplikasi pendaftaran Rawa BaTIK akan diarahkan ke halaman free user. Pada halaman ini pengguna akan ditampilkan data mata kuliah, galeri foto kegiatan dan data merchandise. Gambar untuk halaman free user ditampilkan dalam dua gambar sebagai berikut.

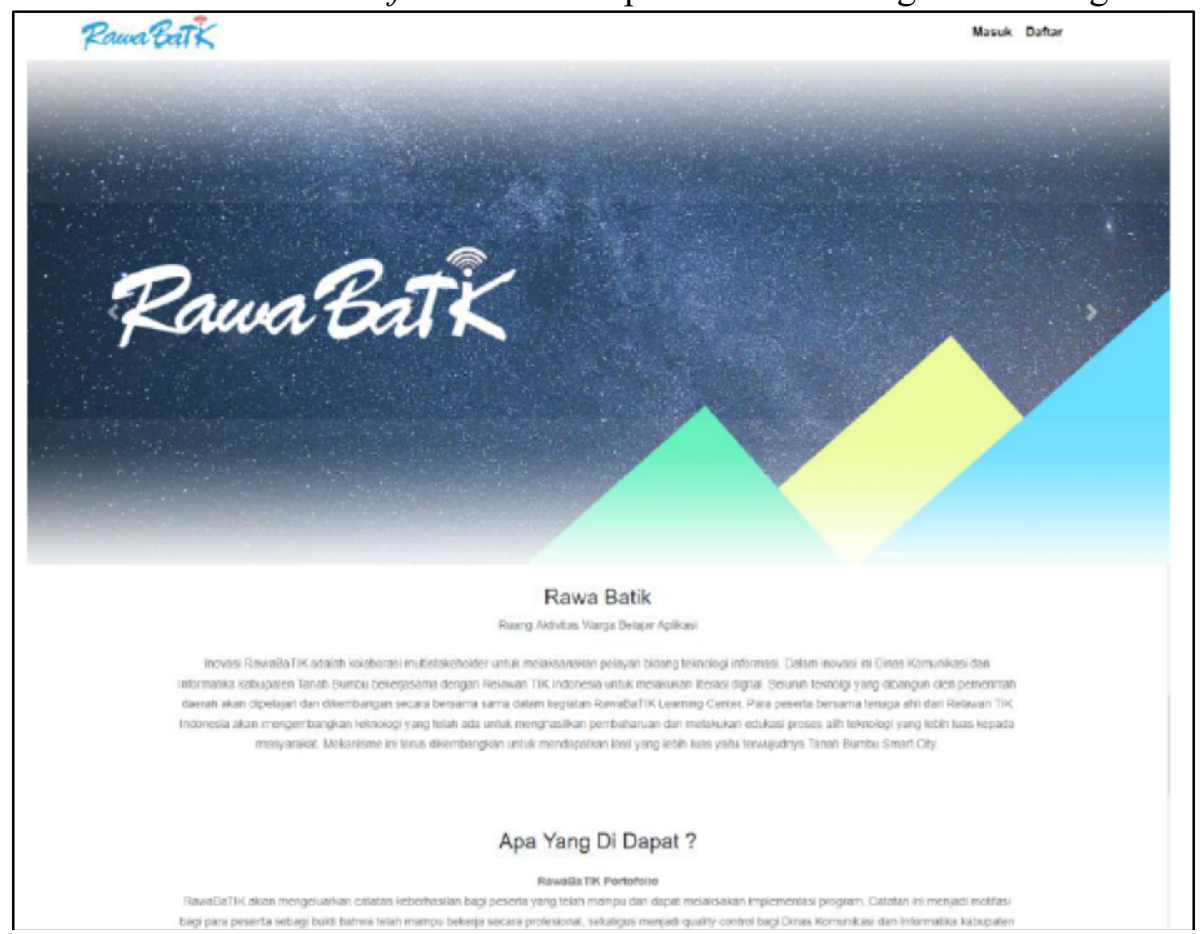

Gambar 9 Halaman free user bagian 1 


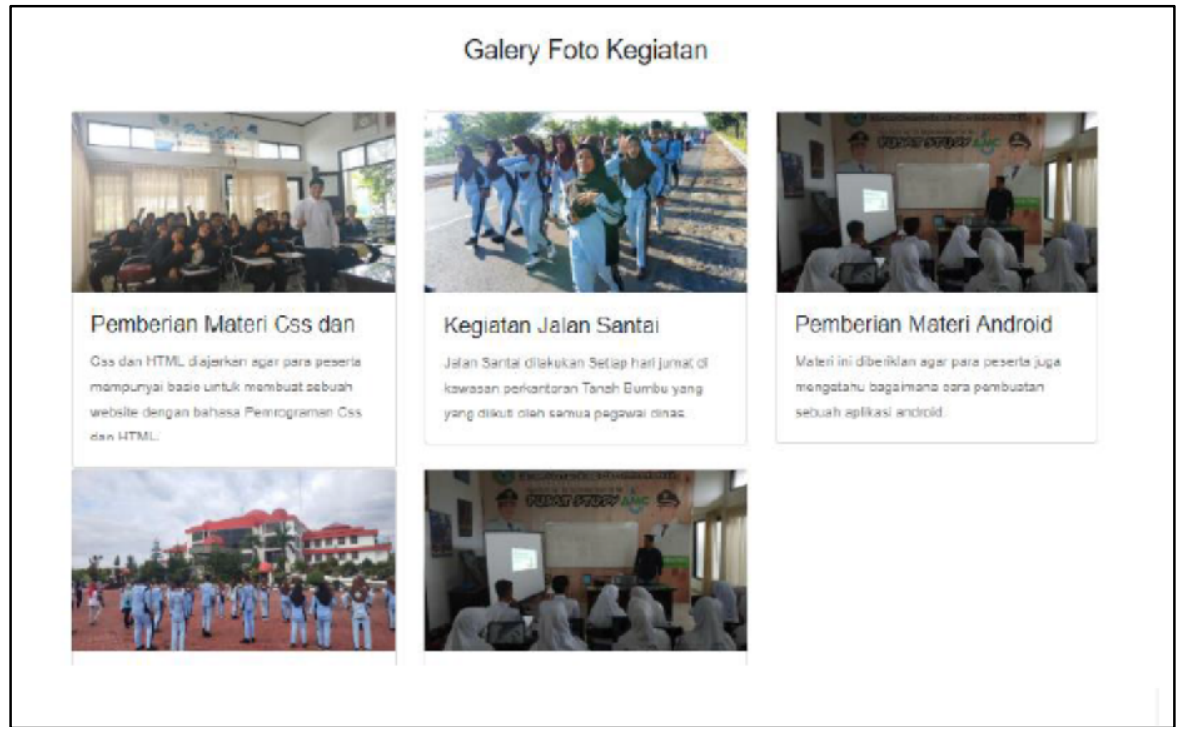

Gambar 10 Halaman free user bagian 2

\subsubsection{Halaman login}

Ketika pengguna memilih menu login yang terletak di pojok kanan atas dari menu halaman free user, maka pengguna akan diarahkan ke halaman login. Tampilan halaman login ditunjukkan pada gambar berikut.

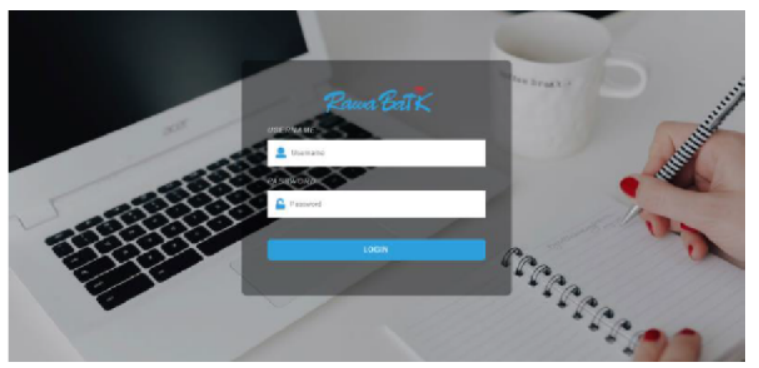

Gambar 11 Halaman login

\subsubsection{Halaman peserta}

Ketika peserta berhasil login, peserta akan diarahkan ke halaman peserta. Pada halaman peserta, diberikan menu agenda, mata pelajaran, peserta, pengajar, galeri dan sertifikat. Tampilan halaman peserta ditunjukkan pada gambar berikut.

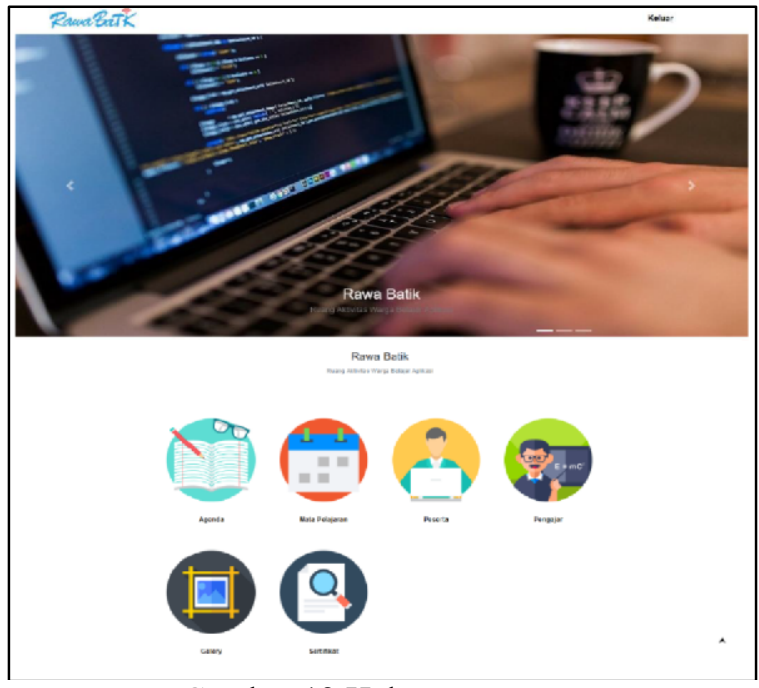

Gambar 12 Halaman peserta 


\subsection{Hasil Pengujian}

Aplikasi pendaftaran Rawa BaTIK telah diuji oleh Sekretaris DISKOMINFO Kabupaten Tanah Bumbu dengan jenis pengujian adalah Black Box Testing. Hasil pengujian menunjukkan bahwa seluruh fungsionalitas dari aplikasi ini telah berjalan seluruhnya. Hasil pengujian ditunjukkan pada tabel berikut.

TABEL 1

HASIL PENGUJIAN BLACK BOX PADA APLIKASI PENDAFTARAN RAWA BATIK

\begin{tabular}{|c|l|c|}
\hline No & \multicolumn{1}{|c|}{ Kasus Uji } & Hasil Pengujian \\
\hline 1 & Login & Berhasil \\
\hline 2 & Kelola akun & Berhasil \\
\hline 3 & Kelola pendaftaran & Berhasil \\
\hline 4 & Kelola peserta & Berhasil \\
\hline 5 & Kelola pengajar & Berhasil \\
\hline 6 & Kelola galeri kegiatan & Berhasil \\
\hline 7 & Kelola merchandise & Berhasil \\
\hline 8 & Kelola agenda & Berhasil \\
\hline 9 & Kelola kelas & Berhasil \\
\hline 10 & Kelola mata pelajaran & Berhasil \\
\hline 11 & Kelola kelas peserta & Berhasil \\
\hline 12 & Kelola sertifikat & Berhasil \\
\hline
\end{tabular}

\section{KESIMPULAN}

Telah dibangun aplikasi pendaftaran Rawa BaTIK berbasis web dengan perancangan aplikasi menggunakan ERD, DFD dan flowchart. Aplikasi dibangun menggunakan bahasa HTML, PHP dan JavaScript. Pengujian telah dilakukan dengan menggunakan metode Black Box Testing dengan hasil pengujian menunjukkan bahwa seluruh fungsionalitas dari aplikasi pendaftaran Rawa BaTIK telah berjalan seluruhnya.

\section{DAFTAR PUSTAKA}

Muslihudin, Muhamad, and Anggun Larasati. 2014. "Perancangan Sistem Aplikasi Penerimaan Mahasiswa Baru Di STMIK Pringsewu Menggunakan PHP Dan MySQL.” Jurnal TAM (Technology Acceptance Model) 3: 32-39.

Palilingan, Kenneth Y.R., Alicia A.E. Sinsuw, and Xaverius B.N. Najoan. 2014. "Registrasi Calon Siswa Baru Berbasis Mobile Android Di Sekolah Menengah Atas Negeri 9 Manado." Jurnal Teknik Elektro Dan Komputer 3 (3): 26-30.

Shahfira, Asridina. 2015. "Aplikasi Pendaftaran Dan Penjadwalan Pertandingan Olahraga Studi Kasus: Koni Kabupaten Asahan Sumatera Utara." E-Proceeding of Applied Science 1 (1): 199-211.

Solihin, Hanhan Hanafiah. 2015. "Perancangan Perangkat Lunak Sistem Informasi Pada Lembaga Kursus Komputer.” Jurnal Ilmu-Ilmu Informatika Dan Manajemen (Informan's) 9 (1): 25-39.

Sukamto, Rosa Ariani, and M. Shalahuddin. 2016. Rekayasa Perangkat Lunak (Terstruktur Dan Berorientasi Objek). Bandung: INFORMATIKA.

Suryanto, Ade. 2016. "Rancang Bangun Sistem Informasi Pendaftaran Artis Berbasis Web Menggunakan Model Waterfall (Studi Kasus: Team Management Agensi)." Jurnal Khatulistiwa Informatika 4 (2): 117-26. 